ARTICLE

DOI: $10.1057 /$ s41599-018-0192-7

\title{
EU policies concerning Lebanon and the bilateral cooperation on migration and security - new challenges calling for new institutional practices?
}

Peter Seeberg ${ }^{1}$

\begin{abstract}
Arguing that a security-stability nexus is a dominant theme in shaping the EU's foreign policy approach towards recent challenges in the Mediterranean, the article applies a historical institutionalist theoretical framework when analysing EU policies concerning Lebanon. The article discusses how the EU-Lebanese cooperation in the light of the unstable political environment in Lebanon is being impacted by the Syrian crisis and how this has been dealt with by EU institutions. It is argued that significant changes in the EU's policies and practices over recent years have taken place. Related to the EU-Lebanon Association Council decision of November 2016 launching the EU-Lebanon Compact, new institutional systems and practices are established regarding cooperation within areas where the EU and Lebanon share common interests. Finally, it is shown that the EU's institutional setup in connection with the Compact represents a pragmatic approach, which, dealing with a crisis situation, aims at making concrete and tangible practices possible.
\end{abstract}

\footnotetext{
${ }^{1}$ Centre for Contemporary Middle East Studies, University of Southern Denmark, Odense, Denmark. Correspondence and requests for materials should be addressed to P.S. (email: seeberg@sdu.dk)
} 


\section{Introduction}

$\mathrm{t}$ is the aim of this article to analyse the EU policies concerning Lebanon focusing on EU-Lebanese institutional relations in the light of the Syrian crisis. The article takes its point of departure in the main bilateral agreements, the EU-Lebanon Association Agreement and the European Neighbourhood Policy (ENP) Action Plans, but concentrates the analysis on the more recent agreements, focusing on the specific challenges related to the significant number of Syrian refugees in Lebanon and the policies dealing with this complex phenomenon. Arguing that a security-stability nexus forms a main theme in shaping the EU's foreign and security policy approach towards Lebanon, the article bases its analysis on historical institutionalism when discussing the institutional setup related to the EU-Lebanese cooperation on migration. The article furthermore discusses to what extend recent EU policies-in particular the so-called EU-Lebanon Compact-represent a pragmatic approach to the challenges for Lebanon related to the Syrian crisis.

An important theme in connection with that is the question of easing the Syrian refugees' controlled access to Lebanese society and to the labour market, the latter obviously a controversial issue (Turner, 2015; ILO, 2014). The article analyses the interests at stake on the sides of both the EU and Lebanon. The two parties share the aim of avoiding a destabilization of Lebanon, but this does not necessarily lead to supporting the integration of refugees in Lebanese society. Furthermore-on the EU side-the reputation of the EU institutions is in focus: it is important to demonstrate to the EU member states that something is being done which eases integration problems in Lebanon, thereby contributing to keeping the majority of the Syrian refugees in countries close to Syria-in casu Lebanon.

In the joint statement following the EU-Lebanon Association Council meeting of July 2017 it was stated that "Recognising the impact of the Syria crisis on Lebanon and the country's extraordinary and exceptional effort in hosting more than 1 million Syrian refugees registered by UNHCR [...], the EU confirmed its willingness to maintain the level of support allocated for 2016-2017 in 2018 and committed to a similar level for 2019" (European Council, 2017b, p. 1). The Syrian crisis with its consequences for Lebanon has become one of the most important aspects of the cooperation between the EU and Lebanon. It is furthermore a significant determinant when it comes to possibilities for Lebanese foreign policy manoeuvring (Fakhoury, 2015, p. 351). Indeed, as argued by Bassel Salloukh: "Nowhere have the spillover effects of the overlapping domestic, regional and international war for Syria proved more devastating than in Lebanon" (Salloukh, 2017, p. 62). The relatively weak Lebanese economy has without doubt been impacted significantly by the critical situation in the region. Lebanon experiences deepening poverty-in particular in the country's poorest localities, where unemployment is alarmingly high (MENA, 2017).

The Arab uprisings in 2011 led to increased and differentiated migration patterns in the Middle East and North Africa (MENA) region, and faced with this reality, the EU created "Dialogues for Migration, Mobility and Security" based on the "Global Approach to Migration and Mobility" (European Commission, 2011). The EU signed Mobility Partnership (MP) agreements with Morocco, Jordan and Tunisia (in 2013, 2014 and 2014, respectively) and initiated talks on an MP with Lebanon in December 2014 (Seeberg, 2017, p. 103). The talks were never completed, but it is still the ambition to pursue the discussions towards the signing of an $\mathrm{MP}$, as indicated in interviews by the author with European External Action Service (EEAS) staff, Brussels (see also European Council, 2017b). In 2016 the scene was set for the launching of a new strategy for the challenges related to migration and refugees by the presentation of the Compact, a set of commitments for the
EU and Lebanon aiming at dealing with the challenges in connection with the Syrian refugees in Lebanon, but also to "provide a beneficial environment for Lebanon, host communities and vulnerable groups" (EU-Lebanon Ass. Council, 2016, p. 12). The Compact describes the suggested (and partly mutual) commitments by the EU and Lebanon aiming at securing the stabilisation of Lebanon in general, but also measures attempting to "provide an appropriate and safe environment for refugees and displaced persons from Syria during their temporary stay in Lebanon" (EU-Lebanon Ass. Council, 2016, p. 12).

The article draws on available sources from relevant EU and Lebanese political institutions, including semi-structured interviews with staff from EEAS and Commission offices, international organisations, and embassies in Brussels and Beirut. The following is structured in three sections, the first of which presents an analytical framework for the article. The next section briefly characterises the impact of the Syrian crisis on Lebanon with a focus on refugees and how this challenge has been handled by the Lebanese regime. After that follows the main section, which first analyses the cooperation between the EU and Lebanon regarding migration, mobility and security, the three dimensions of the talks related to the so far unfinished agreement on an MP, and secondly discusses the EU-Lebanon Compact with the aim of assessing possible perspectives of the agreement.

\section{The EU and Lebanon: migration, mobility and security-an analytical framework}

It is the idea of this section to develop a theoretical framework for the analysis of the recent EU policies vis-à-vis Lebanon aiming at discussing migration, mobility and security-and to present the research question of the article. The framework aims at laying the foundation for analysing ways in which institutions forming part of EU-Lebanese relations develop and adapt to new challenges, drawing on the theory of historical institutionalism (Fioretos, Falleti and Sheingate, 2016; Capoccia, 2016; Dannreuther, 2010). Historical institutionalism's analytical instruments intend to improve our understanding of the particular timing and character of change of the processes analysed. An important methodological concept in this regard is that of critical junctures and the related notion of path dependence. The important benefit of historical institutionalism is that it focuses on the ways in which institutions develop and adapt to new challenges, rather than on how they function-as with more rationalist or functionalist analytical points of departure. Institutions and the legal pathways attached to them can be understood as collections of rules and practices embedded in structures of meaning with the ambition over time to be able to create order and predictability (March and Olsen, 2008, pp. 3-4). Historical institutionalism, as mentioned by Orfeo Fioretos et al., "is a research tradition that examines how temporal processes and events influence the origin and transformation of institutions that govern political relations" (Fioretos, Falleti and Sheingate, 2016, p. 3).

The article is inspired by Roland Dannreuther's work on the Middle East Peace Process, and the understanding that what constitutes an institution has become more broadly defined (Dannreuther, 2010, p. 190). Historical institutionalism attempts to theorise over political action influenced by new institutional developments, or, with Sven Steinmo and Kathleen Thelen, "historical institutionalism represents an attempt to illuminate how political struggles are mediated by the institutional setting which take place" (Steinmo and Thelen, 1992, p. 2). It is furthermore underlined that historical development is seen as a central element in the analysis-historical institutionalism focuses on interaction over time, allowing the analysis to describe and 
interpret elements of continuity, as well as change. Through the analysis of the institutions, political agreements and attached rules and practices, the ambition is to discuss how the EU has pursued its foreign policy strategies in Lebanon. And based on this process-tracing approach, the idea is to follow the development of the EU-Lebanon cooperation over the last decade-with a focus on the Syrian crisis and its impact on Lebanon. Building on this analytical point of departure, the article poses the following research question: To what extent have the institutional relations between the EU and Lebanon been shaped by spillover effects of the Syrian crisis?

The cooperation between the EU and Lebanon from the start of the Arab uprisings in 2011 leading to negotiations about an MP agreement and to the development of relations based on the EU-Lebanon Compact takes place through a complex set of institutional relations. Analysing these relations in the context of EU-Lebanese cooperation, historical institutionalism can offer specific methodological advantages. In the case of the institutional relations between the EU and Lebanon, the crisis following the Arab revolts in 2011 can be seen as an initial critical juncture, where the involved actors - the EU and Lebanon-are faced with significant challenges. The development of the bilateral relations between the EU and Lebanon over the following years demonstrates how the two actors' response to the critical juncture provides evidence of path dependence.

New challenges related to the increasing effects of the Syrian refugee crisis create a new critical juncture both for Lebanon and for the EU, and the way in which it is responded to by the two actors seems to demonstrate that decisions of the past influence or even constrain options left for the involved actors. By viewing the complex relations between the EU and Lebanon through the lenses of historical institutionalism, it becomes possible to identify mechanisms whereby specific institutional responses to given critical junctures to some degree are determined by earlier practices. This, however, should not be understood in a deterministic way. Historical institutionalism does not ignore differing conceptions of specific challenges but opens for the understanding of patterns of continuity and change in the analyses of EU-Lebanese relations.

With the EU's new Migration Partnership Framework of June 2016, it was the ambition that migration should become an integrated and decisive part of EU foreign policy (European Commission, 2016). In a short-term perspective, all current efforts should be continued in order to counteract human smuggling and trafficking and to prevent deaths in the Mediterranean Sea. Furthermore, the policy aimed at increasing the return of migrants without a legal claim to stay in Europe and supporting activities enabling migrants and refugees to remain closer to their country of origin, thus avoiding the often dangerous journeys towards Europe. In the longer run, it was the ambition to address the root causes of migration through an approach where the partner countries were supported in their social and economic development (Seeberg, 2018).

The MPs and the negotiations leading to them have been criticised for being too restricted, temporary and selective (Geddes and Hadj-Abdou 2018, p. 153; Carrera, den Hertog and Parkin 2013 , p. 1). Rather than focusing on the background to the migratory movements, the MPs tend to view the phenomenon from the perspective of the EU, which first of all means that the partner states in the south should accept that within the specific programmes only minor numbers of legal migrants would reach the EU. Furthermore, there would be a focus on external border management and cooperation on the security dimensions of migration. Andrew Geddes and Leila Hadj-Abdou have analysed how international migration is understood by the actors involved in the migration governance systems at the EU level and also at the level of the EU member states. By applying an issue-framing approach, Geddes and Hadj-Abdou seek to "account for influences derived from interactions within the EU migration governance field" (Geddes and Hadj-Abdou, 2018, p. 144), involving government and EU officials, political leaders, business life or trade unions. The idea of looking at EU migration management from a security-stability perspective has been suggested by Roberto Roccu and Benedetta Voltolini, who argue that the preservation of stability in the MENA region aiming at maximising EU security has long been identified as the main ambition of EU's policies vis-à-vis the southern Mediterranean (Roccu and Voltolini 2017, p. 1).

Roccu and Voltolini contend that the link between security and stability-the security-stability nexus-can be perceived as a "master frame" shaping the EU's overall approach to the region. Given changing political, social or economic conditions in the Mediterranean, a need for a reframing might occur, making it possible to make sense of new challenges and provide new ways of dealing with the security-stability nexus. Frames should thus be understood as processes of social construction both within the $\mathrm{EU}$ and between the EU and its partners in the actual situation. It is therefore necessary to analyse the specific actors and their forms of involvement in the given context. This underlines that the analysis should focus on path dependence and trace changes over time in the EU engagement with the Arab Mediterranean states - seeking to understand how the changing policies and practices are pursued and legitimised.

In order to utilise insights from the historical institutionalism approach, this article looks more closely at the development of the EU-Lebanon relations regarding migration, mobility and security and how this development has been impacted by the changes taking place in the Middle Eastern states since the Arab uprisings in 2011. In connection with that, it is relevant to include changes which have taken place in the EU's institutional and legal setup related to cooperation between the EU and Lebanon-with which the EU has had political agreements for several decades. The basis for the cooperation is founded in the EU-Lebanon Association Agreement of 2002 (entering into force in 2006) and the ENP, starting with the first ENP Action Plan adopted by the EU and Lebanon in Oct. 2006 and Jan. 2007, respectively, stating that "The European Neighbourhood Policy offers through its Action Plan a strategic tool for the EU to accompany Lebanon in its Reform process" (European Commission, 2007, p. 1).

The first EU-Lebanon ENP Action Plan, as mentioned adopted by Lebanon in 2007, was not very elaborate and left an impression of having a (more or less) hidden pragmatic and realist agenda on the part of the EU (Seeberg, 2009, p. 94). The period since 2007 has witnessed an in many ways problematic political and economic development in the Levant, not least after 2011, and while attempting to deal with the challenges, the EU has launched both new policies and changes in the institutional and legal setup managing the political ambitions. In short it seems relevant to apply an analysis which includes both the changing policies and the changing institutional and legal setups-while discussing updated versions of former agreements and new policies attempting to solve new political challenges, but also the creation of new EU institutional and legal frameworks for the negotiation and implementation of the policies, within or related to the EU-Lebanese cooperation on migration, mobility and security.

\section{Political development in Lebanon and the conditions for EU-Lebanon partnership}

The long history of Syrian influence in Lebanon in combination with the close relations between Hezbollah and the Syrian regime played a significant role in the first years of the Syrian crisis after 
2011 and led to a situation where it was impossible to find common ground in the Lebanese parliament. This was, for instance, the case when questions of condemnation of the Syrian atrocities were on the agenda in the UN Security Council, and in this context the government therefore distanced itself from the UNSC statement (Geukjian, 2014, p. 543). As described by Zafer Kizllkaya, there was an initial period of low-level involvement by the Hezbollah in Syria, but after the Qusayr offensive, lasting from April to June 2013, in which 1700 Hezbollah fighters took part, Hezbollah no longer hid their involvement on the side of the Ba'ath regime (Kizılkaya 2017, p. 213).

This was later followed by different regional interventions by Hezbollah (in Yemen, Iraq, etc.), which, not surprisingly, were strongly criticised by the GCC states (Legrenzi and Lawson, 2016, p. 31). The role of Hezbollah also worries the EU. It is therefore a long-term goal of the EU to strengthen the official Lebanese army, aiming at balancing off the dominance of Hezbollah (interview, Office for Strategy and Instruments of the ENP, EEAS, Brussels). The combination on one side of the problematic relationship between the EU and Hezbollah and on the other side the complexity of the internal sectarian divide in Lebanon underlines the relevance of applying the critical junctures model to illuminate the historical developments.

Obviously the intervention by Hezbollah in the Syrian war has had severe consequences for internal political stability in Lebanon. It has significantly deepened the sectarian divide in Lebanon, as the "anti-regime and pro-regime mobilisation along largely Sunni-Shia fault lines led to an increase in conflict and agitation" (Salloukh, 2017, p. 69). The internal conflicts in Lebanon intensified, not least in northern Lebanon, where hostilities between pro-Syrian Alawites and pro-opposition Islamist Sunni groups escalated into armed conflict. But also other parts of Lebanon saw expressions of the high level of instability, as when the chief of the Lebanese Intelligence Bureau of the Internal Security Forces, Wissam al-Hassan, was assassinated in a Christian neighbourhood in Beirut, and rumours had it that Hezbollah and/or Syria were responsible for the huge car bomb, which also killed seven bystanders and injured many more (Chulov, 2012). Even if this were the case, there is hardly any doubt that the incident, in combination with many other conflicts and incidents in Lebanon in 2012-2013, led to an aggravated Sunni-Shia division in Lebanon-and the overall result was that the polarisation paralysed the political establishment and its institutions (MENA, 2017).

The unrest intensified as the fighting in Syria was transferred so to speak to Lebanon. Following assaults by jihadist groups (particularly Jabhat al-Nusra; in 2016 renamed Jabhat Fatah al-Sham) in Syria, which attacked Hezbollah's forces there, Lebanon experienced further attacks and suicide bombings-both against Hezbollah facilities and against the Lebanese army. The high number of attacks as a result of the extremely tense political and security environment do not really have any parallel in the region. As listed by Zeinab Cherri, Pedro Arcos González and Rafael Castro Delgado, "a series of 29 suicide bombings and assassinations occurred between October 2012 and November 2015 leading to the death of 205 individuals and injuring 1796 others; the vast majority of victims were civilians" (Cherri, González and Delgado, 2016, p. 170).

Analysing in which ways and to what extent Lebanon has been affected by the crisis in Syria and how this has influenced the cooperation between the EU and Lebanon is empirically challenging. The economic dimensions of the spillover effects of the Syrian crisis in Lebanon underline the difficulties in reversing the situation. The historical institutionalist approach with its focus on continuity and change can in this case help to understand a lack of development. This, however, does not mean eternal stability.
Events which in the first place might seem relatively insignificant can set in path courses of action which become difficult to reverse and might lead to an increasingly destabilised situation. As indicated by several of IMF's country reports, the Syrian crisis has impacted Lebanon in most sections of its economy. Nevertheless, it is difficult to disentangle the channels through which the effect might be measured, partly because the economy was softening already when the conflict in Syria took its beginning in the first months of 2011, and partly because data in general are insufficient and unreliable (Jarmuzek, Nakhle and Parodi, 2014, p. 3).

The IMF 2014 Lebanon Country Report furthermore stated that "the economic, social and political costs of hosting the refugees have become the most visible effects of the crisis" (ibid., p. 3) and mentioned a list of channels with a particular emphasis on the fiscal costs and the impact on the labour market. Tourism also constitutes a field where the effects seem indisputable: the decline in the number of tourist arrivals in Lebanon is a result of the general deterioration in security and also, more tangibly, because the fighting in Syria blocked all land routes to Lebanon for GCC visitors. As shown in the 2014 IMF report, in "2013, tourist arrivals were 60 percent of their 2010 level” (Jarmuzek, Nakhle, and Parodi, 2014, p. 5). Three years later, the overall negative situation was unchanged, as stated in a press release following an IMF staff visit to Lebanon: "Lebanon's economic conditions remain challenging and regional spillovers continue to dominate the near-term outlook. Lebanon has provided a safe haven for over a million Syrian refugees-estimated to be about a quarter of the population" (IMF, 2017b). The press release furthermore noticed that even though the Lebanese economy is known for its resilience, there was an urgent need to place the economy on a sustainable path and stop the increase in the public debt, which in 2016 reached 148 per cent of GDP.

As the Syrian crisis escalated, the number of Syrian refugees seeking safety in Lebanon increased dramatically. In November 2011, 8875 refugees were registered by UNHCR in Lebanon; almost all were Iraqis, with 1 per cent being Syrians (Chaaban et al., 2013, p. 25). In July 2012, UNHCR had registered 33,382 Syrian refugees in Lebanon. Less than a year later the number had increased more than tenfold and in late 2014 it reached a peakmore than 1.1 million (UNHCR, 2018; ILO, 2014, p. 12), resulting in a situation where Lebanon hosted by far the highest proportion of refugees worldwide (ESCWA, 2015, p. 39). The crisis in Syria continued, and it became increasingly difficult to find ways of integrating the refugees in Lebanese society. An ILO report from 2014 showed that the Syrian refugees first of all became employed in agriculture, but also in domestic or personal services and in construction (ILO, 2014, p. 9).

Lebanon, contrary to Jordan, officially practised a nonencampment policy, which in the first years after the start of the civil war in Syria made it possible for Syrian refugees to escape to Lebanon and in many cases get a job. According to the mentioned ILO 2014 study, the participation of the Syrians in the Lebanese labour market was approximately at the same level as Palestinian refugees-and with the same gender-based differences, meaning that the female participation rate was much lower than that of their male counterparts (ILO, 2014, p. 24). Still the unemployment rate among both sexes, albeit difficult to estimate in a reliable way, was quite high. An ILO study from 2015 reiterated that significant population movements had been a central feature of the Lebanese labour market for many years, and also that due to the porosity of the border between Lebanon and Syria, which contributes to creating a significant and unregulated migration towards Lebanon, it was only possible to give rough estimates of the actual economic activity of the Syrian refugees in Lebanon (Ajluni and Kawar 2015, p. 33). 
The character of the economic activity saw some changes over time, which can be divided into two main periods. In the first period, from 2012 to 2014, the estimated economic activity was distributed such that service and agricultural production were the main fields of work (36 and 28 per cent, respectively). It should be mentioned that around one third of the Syrian refugees were living in the Bekaa Valley, where agricultural production primarily takes place (Ajluni and Kawar 2015, p. 34). The age distribution was different from the population of the host country, Lebanon. Around 65 per cent of all registered Syrian refugees were under the age of 25 (Errighi and Griesse, 2016, p. 14). This in itself had obvious consequences for employability, but furthermore, as emphasised by Lorenza Errighi and Jörn Griesse, in addition to the age issue, educational attainment and general skills were low for young refugees (Errighi and Griesse, 2016, p. 14; see also Verme et al., 2016, p. 34).

Regarding skills for adult Syrians, it was estimated by the ILO that 45 per cent were unskilled, while 43 per cent could be considered semi-skilled (ILO, 2014, p. 26). Syrian refugees were for the large part to be considered as a vulnerable group, as convincingly shown by Verme et al. (2016, p. 10). There is no doubt that many of the refugees have been exposed not only to low wages, a lack of a legal basis for their employment, and having to accept work without a contract or stipulated work hours, etc., but also to arbitrary treatment regarding work conditions, in some cases maltreatment or abuse. The refugee group as a whole was dependent on the good will of the given employer. This is also the case for other groups of refugees or migrants, in particular female labourers from Asia, as shown by McCormack, Larsen, and Husn (2015, p. 25), James Sater (2013, p. 132) and others.

In the second period, from 2015 onwards, the number of Syrian refugees registered by UNHCR in Lebanon stagnated, so that the figure from 2014 was followed by a stable situation at a marginally lower level (2015: 1,088,231; 2016: 1,031,303; 2017 : 1,001,051; 2018: 997,552 (UNHCR, 2018)). The stagnation in the influx was first of all a result of changes in legal practices, according to which it became more difficult to enter Lebanon and in particular to be legally allowed to stay there (Janmyr, 2016, p. 78 ). From 2015, Syrian refugees were required to sign an agreement according to which they accepted not working during their stay in Lebanon. In some cases, through sponsorships and work permits, they were accepted as migrant workers, but they were still counted as refugees by the UNHCR. Exceptions to the pledge not to work could be granted, however, if there was a labour shortage or the jobs did not meet the income expectations of the Lebanese labour force (Errighi and Griesse, 2016, p. 11).

Interviews and informal enquiries with international organisations and EEAS staff in Lebanon indicate that while the refugee population as a share of the total population in Lebanon had stabilised since 2014 at around 20 per cent, a higher degree of "normalisation" has emerged, returning Lebanon to a situation similar to before the start of the Syrian crisis, when, as mentioned, hundreds of thousands of Syrians came to Lebanon to work. This was despite the official "pledge not to work" system, which seems to be countered by the high level of informal work-in particular within the agricultural sector and within different forms of work within the service sector. In June 2016, this pledge was abolished and replaced with a pledge to abide by Lebanese law. It remains, however, unclear to what extent this softening of the rules has been implemented throughout the Lebanese institutional system related to work with the refugees. The refugee crisis, since 2014 at an extremely high level, represents a new critical juncture for the relationship between the EU and Lebanon. A logic of path dependence seems to have appeared in the years after this, where a stable, yet potentially disruptive, situation has become a reality.
The EU and Lebanon converge on a common understanding of how to manage the challenges related to this new critical juncture and are developing policy approaches according to which the situation should be kept fairly stable.

\section{EU-Lebanese institutional cooperation on migration, mobility and security-and the EU-Lebanon compact}

As mentioned in the introduction, the eighth session of the Association Council of the EU and Lebanon took place in July 2017, chaired by Lebanese Foreign Minister Gebran Bassil and EU High Representative Federica Mogherini. Since the start of the Syrian crisis in 2011, the EU has allocated more than $€ 1.2$ billion in financial support to Lebanon. The support includes bilateral aid via the different EU-Lebanon cooperation programmes and financial support aimed at addressing the consequences of the Syrian crisis for Lebanon (European Council, 2017b, p. 1). As stated in the press release following the Association Council meeting,

EU and Lebanon discussed the implementation of the Partnership Priorities and EU-Lebanon Compact adopted in November 2016 and confirmed their ambition to intensify the dialogue on issues of mutual interest and cooperate across interrelated areas from counter-terrorism to fostering growth and job creation, in particular for women and youth, strengthening the rule of law and democratic governance and working on migration and mobility. (European Council, 2017b, p. 2)

The ambition of working together on migration and mobility as part of the cooperation between Lebanon and the EU is no novelty. Article 64 in the EU-Lebanon Association Agreement of 2002 underlines that migration is an important issue for both parties and that illegal migration should be considered an issue which must be dealt with as part of the cooperation (European Council 2006, p. 48). When the first ENP Action Plan was agreed upon in 2007, migration had become an even more important issue, as could be seen from the document (European Commission, 2007, pp. 17-19). Since then, the EU institutions aiming at enhancing the cooperation between the EU and Lebanon have been sought to be strengthened at all levels. This goes for EUfunded institutions like the European Instrument for Democracy and Human Rights, but first of all the creation in 2009 of the EEAS with an ambition of launching a more coherent EU foreign policy-in practice via the EU delegation in Beirut-has led to increased bilateral cooperation (Fakhoury, 2014, p. 134).

The Arab spring-migration and mobility. The major concern for the EU is Lebanon's low level of national economic and political stability, exacerbated by the spillover effects of the Syrian crisis, which can be seen as a major critical juncture in EU-Lebanese relations. In connection with that, the EU decided in 2013 to implement a rather unusual measure when it was decided to enter the armed wing of the Hezbollah on the EU's list of terrorist movements (Black, 2013). The European action was initially explained by referring to an alleged involvement of Hezbollah in a terror attack in Bulgaria in 2012, but the main reason behind the political decision was probably the active participation of Hezbollah in the civil war in Syria. It was said in connection with the EU decision that the EU would maintain contact with political parties in Lebanon, including Hezbollah, at that time part of Lebanon's government. It is important for the EU to maintain functioning political relations with Lebanon and to uphold an understanding of common interests between the two parties. This is in accordance with EU-Lebanese agreements within the ENP framework, as mentioned earlier. However, the 
logic of path dependence does not ignore that changes can occur as a result of unexpected political processes-as in the case of the alleged Hezbollah terror attack in Bulgaria.

To an increasing degree migration had become an item which in several different contexts was connected to securitisation processes and therefore was seen as a phenomenon which both the EU and Lebanon saw as important to deal with as part of their bilateral cooperation. Security is constantly an important element in the framing of the EU-Lebanese cooperation, with recommendations for reforming the security sector's capability, conduct and accountability, promoting counter-radicalisation measures, and enhancing the national response to the Syrian refugees (Seeberg, 2018, p. 341). In December 2014, initial talks took place on a possible MP between the EU and Lebanon, characteristically, and in accordance with the frequently seen framing, dubbed a "dialogue on migration, mobility and security" (European Commission, 2015, p. 10). It was the ambition in 2015 to carry on discussing the issues identified during the start of the dialogue, but in reality, the dialogue turned out to be difficult to keep running-primarily due to the political crisis in Lebanese politics. However, given the in many ways problematic situation in Lebanon and in the regional environment around it, it was not surprising that the development of bilateral relations between the $\mathrm{EU}$ and Lebanon for a while found itself at a standstill. The tense situation in 2015 constituted a potentially critical juncture in the cooperation between the EU and Lebanon.

The London Conference in February 2016, formally hosted by Germany, Kuwait, Norway, the United Kingdom and the United Nations, could be seen as a step towards renewed contacts. As a point of departure, an estimate by the World Bank was mentioned, claiming that "Lebanon has incurred losses of $\$ 13.1$ billion since 2012 out of which $\$ 5.6$ billion in 2015 alone (over $11 \%$ of GDP), as well as massive impacts on public services including education, health, energy, water, waste collection and treatment and infrastructure, all of which had been strained even before the crisis" (Statement of Intent, 2016, p. 1). Following key messages on the necessity of helping Lebanon, the document, officially presented as a "Statement of Intent", focused on two main areas where the international funding should be utilised, namely education and economic opportunities, and jobs for Syrian refugees and for unemployed Lebanese workers.

New realities and approaches. The notion of path dependency can help identify expressions of institutional stability and change. In this case the cooperation between the EU and Lebanon aims at constructing an agreement on how to manage the challenges related to the refugees present in Lebanon as a result of the Syrian crisis. It is important to maintain a consensus between the two partners that working together is the only sensible way forward. A new approach which might make this possible is therefore called for.

The Association Council decision of 11 November 2016 agreeing on EU-Lebanon Partnership Priorities reflects a different institutional approach in which the recent challenges are in focus. As an annex to the Partnership Priorities, an EU-Lebanon Compact is attached, taking its point of departure in the revised ENP and the London Conference "Supporting Syria and the Region". Here it is stated that the "EU-Lebanon Compact, guided by Partnership Priorities, will define priority actions to support the stabilisation of the country" (Council, 2016, p. 11).

The Compact is framed in a way which very directly reflects the recent situation, pointing to the needs of the Syrian refugees (in the Lebanese discourse termed "displaced persons from Syria"). The Annex text has the character of a mutual agreement between the EU and Lebanon, where Lebanon commits "to continue seeking, in conformity with Lebanese laws, ways to facilitate the streamlining of regulations governing their stay, including periodical waiver of residency fees and simplifying documentary requirements such as the 'pledge not to work', with a view to easing their controlled access to the job market in sectors where they are not in direct competition with Lebanese, such as agriculture, construction and other labour intensive sectors" (Council, 2016, p. 12). With this policy tool, the EU and Lebanon are adapting to the new critical juncture. The different aspects of the Compact together form part of a set of policy instruments which are characterised by a lack of formalisation. They are developed based on a pragmatic agenda which aims at solving problems in cooperation.

The EU for its part has promised to provide financial aid for the different purposes listed in the Compact. Added to that, other donors, states and financial institutions have pledged financial assistance. At the London Conference, plans were presented which, according to the World Bank, call for $\$ 11$ billion for the period 2016-20 comprised of grants ( 5 billion) and loans (6 billion) (IMF, 2017a, p. 5), even though, of course, there is no guarantee that the total financial aid from the different donors will ever reach this level. It is in the interest of the EU to live up to its promises, thereby creating the financial means for the different actions listed in the Compact. In the mentioned Annex to the EU-Lebanon Association Council decision, the Compact introduces a list of measures to be carried out to which the two partners have committed themselves. These commitments, arranged synoptically for the two parties, are listed under four main headings: 1. Enhancing Stability: Security and Counter-terrorism; 2. Governance and Rule of Law; 3. Fostering Growth and Job Opportunities; 4. Migration and Mobility (Council, 2016, pp. 13-19).

Concerning security and counterterrorism, the idea is that, with the support of the EU, Lebanon shall develop a national counter-terrorism strategy, which in its turn involves relevant EU institutions, EU Member State experts, Europol, Cepol, FRONTEX and Eurojust. The description in the Annex regarding governance and rule of law is not very elaborate in its wording and/or substance, which probably can be seen as an indirect indication that this item is not the main priority in the context of the Compact. As indicated in an interview with staff at the European Commission, the viewpoint on the part of the EU within this field seems to be "not to rock the boat too much", avoiding putting pressure on Lebanon in the recent situation. Regarding growth and job opportunities, the overall aim is to address Lebanese macroeconomic imbalances and vulnerabilities -thereby mitigating the Syrian crisis. It is no secret that fostering job opportunities for Syrian refugees in Lebanon will tend to be unpopular among the Lebanese population. Therefore, the ambition of liberalising EU customs conditions-via the socalled Rules of Origin system (European Council, 2017b: p. 2)creating easier access for Lebanese commodities to the European market might be an interesting idea. However, this is an area within which the EU's relatively strict environmental regulations can result in limitations on the actual trade between the EU and Lebanon (interview, EEAS, Brussels).

Finally, concerning migration and mobility, in a text which states that the "core objectives of the EU-Lebanon Compact are both to provide an appropriate and safe environment for refugees and displaced persons from Syria, during their temporary stay in Lebanon, and to provide a beneficial environment for Lebanon, host communities and vulnerable groups" (Council, 2016, p. 12), it seems a bit surprising that not only is migration and refugees the last item to be covered, but in particular the description of the theme in the Compact is rather general, not to say superficial. Basing the interpretation of this reality on the notion of path 
dependence, the explanation is that, in order to maintain a consensus between the EU and Lebanon, the new agreement has to be formulated in general terms. Insisting too much from the side of the EU might challenge the fragile mutual understanding.

One of the novelties of the document is the pledge, despite significant unemployment in Lebanon, to create through a set of interventions 300,000-350,000 new jobs in Lebanon, of which $60 \%$ should be reserved for Syrians living there. The interventions are to first of all take place within the fsollowing four areas: projects based on investments in municipalities, among them a new flagship programme called the "Subsidised Temporary Employment Programme" (known as STEP); programmes (in cooperation with the EU and the World Bank) to secure easier access to international markets and investments in urgent national-level infrastructure needs, in practice Lebanon's solid waste crisis; measures to rebuild the Nahr-el-Bared camp; and prison expansion and improvements (Statement of Intent 2016, p. 3 ). Obviously there was only a low level of consensus behind this, in particular regarding the idea of offering more than half of the newly created jobs to Syrians.

In the joint statement of 18 July 2017 by Federica Mogherini and Gebran Bassil from the EU-Lebanon Association Council meeting, it was mentioned that the "Association Council also agreed to pursue the discussions towards the signature of a Mobility Partnership" (EU Council 2017b, p. 2). This, however, seemed to be a perspective in connection with which some reluctance was observable on the Lebanese side. As explained in an interview with staff at the EEAS office in Brussels, the MP could initially be seen as a suggestion on the part of the EU related to the specific conditions concerning the Arab Spring in the first half of 2011. There were discussions between the parties and even a text which was not very far from a possible final agreement. However, events in the region and the internal political crisis in Lebanon put the negotiations on hold. It was the understanding in Brussels that a signed agreement (in the form of a finalised MP) was seen as involving a level of commitment which Lebanon for the time being was not ready to accept, partly because it might tend to codify the permanent presence of the Syrian refugees in Lebanon, and partly because the Lebanese feared being tied to agreements they considered as being "too tangible" on visas and readmission.

From the side of the EU, readmission and return have over recent years become some of the most important elements of EU policies within this field. A formal, yet significant institutional indication of this can be seen in the fact that from 2014 to 2018 the staff of the office for Irregular Migration and Return Policy has grown from two to thirty employees (interview in European Commission, DG for Migration and Home Affairs). In the press conference following the Association Council meeting in July 2017, Gebran Bassil commented on the problems related to the continued presence of a high number of Syrian refugees in Lebanon:

We are still confronted with the negative repercussions of the mass influx of the Syrian nationals displaced into our country $[. .$.$] financially we feel that the donors have shown$ some signs of fatigue [...] informal settlements and camps have been the scene behind which terrorist organisations and individuals have sought refuge, representing a security threat for both the displaced and their host (transcript from press conference, European Council, 2017a).

The historical institutionalist approach conforms well with the ways in which the understanding of the main issues regarding the "Syrian nationals" were presented by Bassil in 2017. Seen from his official viewpoint Lebanon is exposed to extremely difficult problems which the EU and Lebanon have to attempt to solve together. Despite being a generous host for large groups of refugees, Lebanon is not a full signatory of the 1951 Refugee Convention (Betts and Collier, 2017, p. 42)-therefore the reference to Syrian nationals. The comments by Bassil furthermore underline that the recent situation perceived from the Lebanese perspective is very different from the situation after the Arab Spring, where the uprisings in the Arab World pointed in the direction of democratic progress and institutional change. The recent situation calls for a development of the institutional setup behind EU-Lebanese cooperation and for pragmatic solving of significant recent political, social and economic challenges. Lebanon sees itself as an open society, which-with limited resources-handles larger numbers of Syrian refugees than the whole of the EU (interview with Lebanese diplomatic staff, Brussels). The Lebanese reluctance concerning the MP can thus be explained by the changing conditions for institutional development. The MP has not been realised because of the regional crisis in the Levant, which asks for urgent measures rather than official agreements. The case thus represents a lack of path dependence in the cooperation between the EU and Lebanon. The development, however, has not led to suspensions of political contacts and negotiations.

Nor have all measures decided upon in other contexts been carried out. The ambition of creating 300,000-350,000 new jobs, of which 60 per cent were to be allocated to Syrian refugees in Lebanon, has not been realised and, according to Agnès Favier, it seems unrealistic that the programme could offer a solution to the employment crisis for the Syrians in Lebanon (Favier, 2016, p. 4; the assessment by Favier was confirmed in an interview by the author with EEAS staff, Beirut). Other undertakings, in some cases parts of existing EU-Lebanon activities like, for instance, the Integrated Border Management (European Commission, 2017a), have been continued and form a part of what might be described as an institutional change of the bilateral agreements into a more practice-oriented direction. It should furthermore be mentioned that the security services of EU member states work closely together with the Lebanese national security agenciesthis is also not a newly established common activity (interview with Lebanese diplomatic staff, Brussels).

The Partnership Priorities agreement and the Compact have been followed by additional initiatives from the EU side aiming at improving the living conditions for the Syrian refugees and for the vulnerable host communities-and, from the Lebanese side, at easing the temporary stay of Syrian refugees in Lebanon. An assistance package aiming at capacity building for conducting "credible, periodical, transparent and inclusive elections" and to develop a decentralised waste management system and local water supply based on the water resources from the Litani river has been decided upon by the EU. This package comes in addition to the support provided by the EU for Lebanon, which since the start of the Syrian crisis amounts to more than $€ 1.2$ billion. Together the EU and Lebanon have "established a Single Support Framework (SSF) for 2017-2020 that frames the EU's financial cooperation around three broad intervention areas: (1) growth and job creation, (2) local governance and socioeconomic development and (3) Rule of Law and enhancing security" (European Commission, 2017c). Interviews in the EEAS office for Strategy and Instruments of the ENP, Brussels, point to giving the SSF-framework a high priority, not least when it comes to the continued cooperation between the EU and Lebanon, and to coming conferences dealing with the impact of the Syrian crisis on its neighbouring countries, in particular Jordan and Lebanon. Summing up, it seems that a logic of continuation dominates regarding path dependence in EU-Lebanese relations. The tendency confirms a main element in historical institutionalism, namely that specific responses to critical junctures tend to lock in specific developmental patterns. 


\section{Conclusion and perspectives}

In June 2017, the EU presented a Country Report on EU-Lebanon relations in the framework of the revised ENP assessing the cooperation between the two partners over the period from March 2015 to April 2017. In the summary, it was stated that "during the reporting period, the EU-Lebanon partnership became closer, more strategic and more focused" (European Commission, 2017b, p. 2). The article has sought to demonstrate that drawing on the theory of historical institutionalism is useful for an understanding of the both complex and unusual historical process when analysing the institutional setup related to the EU-Lebanon cooperation in the context of the Syrian crisis. The crisis constitutes-within the historical institutionalism framework-a critical juncture with potentially wideraging perspectives regarding EU-Lebanese cooperation. Based on this, a new institutional setting was necessary and the EU-Lebanon Compact seemed to provide the answer. Through utilising historical institutionalism as the theoretical approach, it can be argued that the institutional setup related to the Compact represents a pragmatic approach to a critical juncture resulting from the Syrian refugees in Lebanon following the crisis in Syria from 2011 and onwards.

The approach aims at making concrete and tangible practices possible, which can help maintain the new institutional setup, the EU-Lebanon Compact. As mentioned above, it seems that in the given historical context a logic of continuation dominates and expresses a path dependence in EU-Lebanese relations. The main focus areas of the cooperation in the context of the severe regional crises, as referred to by Federica Mogherini in the press release following the launching of the report, are security, counterterrorism and stability, aiming at counteracting the spillover effects of the developments in Syria on Lebanon. As shown in the article, a security-stability nexus is a main frame for the EU's foreign and security policy approach to the Levant, but in particular in connection with Lebanon it is obvious that security and stability are essential foreign policy goals.

As emphasised, there was a connection between the so-called Arab Spring and the EU's ambition of promoting MP agreements in the Mediterranean. This was also the case for Lebanon, but due to the regional turmoil and in particular the internal political crisis in Lebanon, the negotiations came to a stop. The already existing MPs agreed upon between the EU and the Arab Mediterranean states was criticised for representing a security-oriented and control-oriented approach, only allowing limited and selective forms of migration towards Europe and driven by a strong conditionality vis-à-vis the relevant states (Carrera, den Hertog and Parkin, 2013, p. 1).

Taking the situation in Lebanon after 2014 into consideration, it seems obvious that a migration regime primarily aiming at solving problems related to transnational migration towards the $\mathrm{EU}$ as the main focus was not what was asked for. Rather it seemed that an approach which took its starting point in the complex reality of the Syrian crisis and its consequences for Lebanon was relevant. This meant that the cooperation between the EU and Lebanon needed to focus on three phenomena: firstly the very tangible challenges related to the a little less than one million Syrian refugees in Lebanon, secondly a very difficult security situation as a result of the emergence of hostilities in Lebanon which were "transferred" from Syria, and thirdly a chaotic and highly unstable internal situation in Lebanon as a result of the sectarian divide in Lebanese politics, the consequences of which became more pronounced due to the strong position of Hezbollah in Lebanese society and Hezbollah's participation in the war in Syria.

Gebran Bassil underlined in his statement at the Association Council meeting in July 2017 that there is a strong interconnectedness between the arrival of large numbers of refugees from Syria and the problematic security situation in Lebanon. The common interest shared by the EU and Lebanon in reducing the security risks attached to the refugee crisis is a recurring and for both partners highly important theme in the documents and statements from the cooperation related to the EU-Lebanon Compact. Comparing the realities after the Arab Spring in 2011 with the recent situation where the Syrian crisis has unfolded in all its in many ways tragic dimensions, there is hardly any doubt that the present challenges are different, more complex and more challenging. The chosen strategies and institutional arrangements are also, as the above analysis has shown, in many ways different from earlier practices. This seems both to confirm the relevance of the historical institutionalist approach applied in the preceding analysis and to suggest further research dealing with the complexities of the EU-Lebanese cooperation on migration and security.

Received: 10 March 2018 Revised: 12 October 2018 Accepted: 25 October 2018

Published online: 13 November 2018

\section{References}

Ajluni S, Kawar M (2015) Towards Decent Work in Lebanon: Issues and Challenges in Light of the Syrian Refugee Crisis. International Labour Organization Regional Office for Arab States, Beirut. http://www.ilo.org/wcmsp5/ groups/public/---arabstates/---ro-beirut/documents/publication/ wcms_374826.pdf, accessed 1 October 2018

Betts A, Collier P (2017) Refuge. Transforming a Broken Refugee System. Allen Lane, London

Black I (2013, July 22) EU resists Hezbollah ban but lists armed wing as terrorist group. The Guardian

Capoccia G (2016) When Do Institutions "Bite"? Historical Institutionalism and the Politics of Institutional Change. Comp Polit Stud 49(8):1095-1127

Carrera S, den Hertog L and Parkin J (2013, January 24) The 'Arab Spring' and EU's Immigration Policy: A Critical Sociology on the Global Approach to Migration and Mobility. Comment. http://www.mei.edu/content/arab-springand-eus-immigration-policy-critical-sociology-global-approach-migrationand

Cherri Z, González P, Delgado P (2016) The Lebanese-Syrian crisis: impact of influx of Syrian refugees to an already weak state. Risk Manag Healthc Policy 2016(9):165-172

Chulov M (2012, October 19) Lebanon's great divide exposed by assassination of security chief. The Guardian

Chaaban M, Seyfert K, Salti N, El Makkaoui G (2013) Poverty and livelihoods among UNHCR registered refuges in Lebanon. Refug Surv Q 32(1):24-49

Dannreuther R (2010) Understanding the Middle East Peace Process. A historical institutional approach. Eur J Int Relat 17(2):187-208

Errighi L, Griesse J (2016) The Syrian Refugee Crisis: Labour Market Implications in Jordan and Lebanon. https://ec.europa.eu/info/publications/economyfinance/syrian-refugee-crisis-labour-market-implications-jordan-andlebanon_en, accessed 1 October 2018

ESCWA \& IOM (2015) Situation Report on International Migration. Migration, Displacement and Development in a Changing Arab Region. https:// publications.iom.int/system/files/pdf/sit_rep_en.pdf, accessed 1 October 2018

European Commission (2007) European Neighbourhood Policy EU-Lebanon Action Plan. https:/eeas.europa.eu/sites/eeas/files/ lebanon_enp_ap final_en_0.pdf, accessed 1 October 2018

European Commission (2011) The Global Approach to Migration and Mobility. http://eur-lex.europa.eu/legal-content/EN/ALL/?uri=CELEX:52011DC0743, accessed 1 October 2018

European Commission (2015) Implementation of the European Neighbourhood Policy in Lebanon. https://reliefweb.int/report/lebanon/implementationeuropean-neighbourhood-policy-lebanon-progress-2011-and, accessed 1 October 2018

European Commission (2016) Communication from the Commission to the European Parliament, the European Council, the Council and the European Investment Bank (7.6.2016. COM (2016) 385 FINAL). https://ec.europa.eu/ home-affairs/sites/homeaffairs/files/what-we-do/policies/european-agendamigration/proposal-implementation-package/docs/20160607/ 
communication_external_aspects_eam_towards_new_migration_ompact_en.pdf, accessed 1 October 2018

European Commission (2017a) Joint Report to the European Parliament, The Council, the European Economic and Social Committee and the Committee of the Regions. Report on the Implementation of the European Neighbourhood Policy Review. https://eeas.europa.eu/headquarters/headQuartershomepage/26371/report-implementation-european-neighbourhood-policyreview_hu, accessed 1 October 2018

European Commission (2017b) Joint Staff Working Document. Report on EULEBANON relations in the framework of the revised ENP, SWD (2017) 251 final. https://eeas.europa.eu/sites/eeas/files/joint_staff_working_paper_en.pdf, accessed 1 October 2018

European Commission (2017c) New Assistance package for Lebanon: EU strongly committed to supporting the country's development and stability. https://ec. europa.eu/neighbourhood-enlargement/news_corner/news/new-assistancepackage-lebanon-eu-strongly-committed-supporting-countrys_en, accessed 1 October 2018

European Council (2006) Council Decision of on the signing, on behalf of the Community of a Euro-Mediterranean Agreement establishing an Association between the European Community and its Member States, of the one part, and the Republic of Lebanon, of the other part. http://eur-lex.europa.eu/eli/ dec/2015/268/oj, accessed 1 October 2018

European Council (2017a) Association Council 2017, Press conference: Preliminary remarks by Gebran Bassil, Minister for Foreign Affairs and Emigrants of Lebanon, following the EU-Lebanon Association Council, on 18 July 2017, transcript. https://tvnewsroom.consilium.europa.eu/event/eulebanon-3c95/association-council-2017-press-conference-part-3-17fe7, accessed 1 October 2018

European Council (2017b) Joint statement following the EU-Lebanon Association Council, 487/17, 18/07/2017. http://www.consilium.europa.eu/en/press/pressreleases/2017/07/18/eu-lebanon-association-statement/, accessed 1 October 2018

EU-Lebanon Association Council (2016) Decision No 1/2016 of the EU-Lebanon Association Council agreeing on EU-Lebanon Partnership Priorities, 11 November. https://euroalert.net/oj/59709/decision-no-1-2016-of-the-eulebanon-association-council-of-11-november-2016-agreeing-on-eu-lebanonpartnership-priorities-2016-2368, accessed 1 October 2018

Fakhoury T (2014) The EU and Lebanon in the Wake of the Arab Uprisings. Middle East Policy 21(1):133-143

Fakhoury T (2015) Lebanon's Perilous Balancing Act. Curr Hist 350:349-354. December 2015

Favier A (2016) Increasing Vulnerability for the Syrian Refugees in Lebanon: what's next? Middle East Directions: Policy Brief 2016/03

Fioretos O, Falleti T, Sheingate A (2016) Historical Institutionalism in Political Science. In: Fioretos O, Falleti T, Sheingate A (eds) The Oxford Handbook of Historical Institutionalism. Oxford University Press, Oxford, p 3

Geddes A, Hadj-Abdou L (2018) Changing the path? EU migration governance after the 'Arab spring'. Mediterr Polit 23(1):142-160

Geukjian O (2014) Political Instability and Conflict after the Syrian Withdrawal from Lebanon. Middle East J 68(4):521-545

ILO (2014) Assessment of the Impact of Syrian Refugees in Lebanon and their Employment Profile. http://www.ilo.org/beirut/publications/WCMS_240134/ lang--en/index.htm, accessed 1 October 2018

IMF (2017a) IMF Country Report No. 17/19. Lebanon. http://tekobooks.com/ download/imf-country-report-no-17-19-lebanon/, accessed 1 October 2018

IMF (2017b) IMF Staff Concludes Visit to Lebanon. https://www.imf.org/en/News/ Articles/2017/09/13/pr17347-imf-staff-concludes-visit-to-lebanon, accessed 1 October 2018

Janmyr M (2016) Precarity in Exile: The Legal Status of Syrian Refugees in Lebanon. Refug Surv Q 35(1):58-78

Jarmuzek M, Nakhle N, Parodi F (2014) IMF Country Report No. 14/238. Lebanon. Selected Issues Paper. https://www.imf.org/external/pubs/ft/scr/2014/ cr14238.pdf, accessed 1 October 2018

Kızılkaya Z (2017) Hizbullah's Moral Justification of Its Military Intervention in the Syrian Civil War. Middle East J 71(2):211-228

Legrenzi M, Lawson F (2016) Saudi Arabia Calls Out Hezbollah: Why Now? Middle East Policy 23(2):31-43

McCormack S, Larsen J, Husn H (2015) The Other Migrant Crisis. Protecting Migrant Workers against Exploitation in the Middle East and North Africa. https://publications.iom.int/books/other-migrant-crisis-protecting-migrantworkers-against-exploitation-middle-east-and-north

March J, Olsen J (2008) Elaborating the "New Institutionalism". In Binder S, Rhodes R, Rockman B (eds). The Oxford Handbook of Political Institutions. Oxford University Press, Oxford, pp. 2-21

MENA (2017) The Middle East and North Africa 2016. Routledge, London

NOW (2013) Miqati reiterates importance of disassociation policy. https://now. mmedia.me/lb/en/archive/miqati-reiterates-importance-of-disassociationpolicy, accessed 1 October 2018
Roccu R, Voltolini B (2017) Framing and reframing the EU's engagement with the Mediterranean: Examining the security-stability nexus before and after the Arab uprisings. Mediterr Polit 23(1):1-22

Salem A, Kawar M (2014) The Impact of the Syrian Refugee Crisis on the Labour Market in Jordan: A Preliminary Analysis. International Labour Organization. Regional Office for the Arab States, Beirut

Salloukh B (2017) The Syrian War: Spillover Effects on Lebanon. Middle East Policy 24(1):62-78

Sater J (2013) Migrant Workers, Labor Rights, and Governance in Middle Income Countries: The Case of Migrants Domestic Workers in Lebanon. In: Seeberg P, Eyadat Z (eds) Migration, Security, and Citizenship in the Middle East. Palgrave, New York, p 115-136

Seeberg P (2009) The EU as a realist actor in normative clothes: EU democracy promotion in Lebanon and the European Neighbourhood Policy. Democratization 16(1):81-99

Seeberg P (2017) Mobility Partnerships and Security Subcomplexes in the Mediterranean: The Strategic Role of Migration and the EU's Foreign and Security Policies towards the MENA region. Eur Foreign Aff Rev 22(1):91-110

Seeberg P (2018) EU-Mashreq Relations: Differentiation, Conditionality, and Security. In: Demmelhuber T, Marchetti A, Schumacher T (eds) The Routledge Handbook on the European Neighbourhood Policy. Routledge, Abingdon and New York, p 336-347

Statement of Intent, Lebanon (2016) Final: Supporting Syria and the region. http:// webarchive.nationalarchives.gov.uk/20170606121449/https:// 2c8kktlykog81j8k9p47oglb-wpengine.netdna-ssl.com/wp-content/uploads/ 2016/02/Supporting-Syria-the-Region-London-2016-Lebanon-Statement.pdf, accessed 1 October 2018

Steinmo S, Thelen K (1992) Historical Institutionalism in Comparative Analysis. In: Steinmo S, Thelen K, Longstreth F (eds) Structuring Politics: Historical Institutionalism in Comparative Analysis. Cambridge University Press, Cambridge, p 1-32

Saad H, Gladstone R (2014, August 4) Border Fighting Intensifies Between ISIS and Lebanon, New York Times

Turner L (2015) Explaining the (Non-)Encampment of Syrian Refugees: Security, Class and the Labour Market in Lebanon and Jordan. Mediterr Polit 20 (3):386-404

UN \& ILO (2017) Lebanon Crisis Response Plan 2017-2020. http://www.ilo.org/ beirut/areasofwork/syrian-refugee-crisis/lebanon/WCMS_542062/lang--en/ index.htm, accessed 1 October 2018

UNHCR (2018) Syria Regional Refugee Response. Inter-agency Information Sharing Portal. Lebanon. http://data.unhcr.org/syrianrefugees/country.php? $\mathrm{id}=122$, accessed 1 October 2018

Verme P, Gigliarano C, Wieser C, Hedlund K, Petzoldt M, Santacroce M (2016) The Welfare of Syrian Refugees: Evidence from Jordan and Lebanon. http:// www.worldbank.org/en/news/feature/2015/12/16/welfare-syrian-refugeesevidence-from-jordan-lebanon, accessed 1 October 2018

\section{Data availability}

All data generated or analysed during this study are included in this published article

\section{Additional information}

Competing interests: The author declares no competing interests.

Reprints and permission information is available online at http://www.nature.com/ reprints

Publisher's note: Springer Nature remains neutral with regard to jurisdictional claims in published maps and institutional affiliations.

Open Access This article is licensed under a Creative Commons Attribution 4.0 International License, which permits use, sharing, adaptation, distribution and reproduction in any medium or format, as long as you give appropriate credit to the original author(s) and the source, provide a link to the Creative Commons license, and indicate if changes were made. The images or other third party material in this article are included in the article's Creative Commons license, unless indicated otherwise in a credit line to the material. If material is not included in the article's Creative Commons license and your intended use is not permitted by statutory regulation or exceeds the permitted use, you will need to obtain permission directly from the copyright holder. To view a copy of this license, visit http://creativecommons.org/ licenses/by/4.0/

(C) The Author(s) 2018 